\title{
Diagnosis of Types of Diseases in Cassava Plant by Bayes Method
}

\author{
Agung Purnomo Sidik \\ Science and Technology Faculty, Universitas Pembangunan Panca Budi, Medan, Indonesia \\ agung@dosen.pancabudi.ac.id
}

\begin{abstract}
This research was conducted to implement the Bayes algorithm in an expert system to diagnose types of diseases in cassava plants. The research data was taken from the Binjai City Agriculture and Fisheries Office in 2018. The expert system was built based on the web, where the application was built using the PHP programming language and MySQL DBMS. The results showed that the Bayes algorithm can be used in expert system applications to diagnose types of cassava plant diseases. In the Bayes algorithm, the knowledge base is taken from the data of the amount of data from cassava plants that suffer from disease, so the results of diagnosing cassava plants are based on existing data. Therefore, the more patient data that is used as a knowledge base, the better the diagnosis results are given.
\end{abstract}

Keywords: Expert System, Bayes Method, Cassava

\section{INTRODUCTION}

Tubers are plants that have been used by humans for thousands of years as a daily staple food. So that the tubers are cultivated on a large scale given the human need for tubers is still very high. The planted tubers are composed of many types of tubers, such as cassava, potatoes, sweet potatoes, and so forth. As with other plants, tuber plants are also not immune from disease, especially on cassava.

Cassava is known as a plant that is very easy to cultivate. Cassava does not really need land with special conditions, and without special care. So this has become one of the reasons this plant is widely cultivated. Although cassava plants are very easy to cultivate and easy to grow, that does not mean these plants do not have the disease [1]. Based on observations of the Binjai City Agriculture and Fisheries Office conducted in 2018, there were 6 diseases affecting the cassava plants with the following percentage:

Table 1. Percentage of Disease in Cassava

\begin{tabular}{lc}
\hline \multicolumn{1}{c}{ Types of Cassava Diseases } & Percentage (\%) \\
\hline Brown Leaf Spots & 19,65 \\
Baur Leaf Spots & 14,12 \\
White Leaf Spots & 21,91 \\
Leaf Bacteria & 12,09 \\
Anthracnose & 9,07 \\
Rot at the Base of the Stem/Root & 23,17 \\
\hline
\end{tabular}

From the above data, it can be seen that stem rot/root disease is the most dominant disease affecting cassava plants with a rate of $23.17 \%$. Then followed by White Leaf Patches with a percentage of $21.91 \%$, then Brown Leaf Patches with $19.65 \%$, then Baur Leaf Patches with a percentage of $14.12 \%$, and the least is Anthracnose disease with a percentage of 9.07.

Various diseases if left unchecked will cause death in plants that cause crop failure or decreased production. If this happens, it will be detrimental to farmers specifically, and in general, will cause cassava scarcity in the market which will increase the price of cassava.

Many beginner cassava farmers do not really understand the diseases that occur in their plants, so sometimes they just let the plants get the disease without doing any treatment to prevent the disease from infecting other plants. This occurs due to the lack of information known by farmers about cassava plant diseases.

The development of information technology, especially the rapid development of artificial intelligence provides a lot of convenience for humans to more quickly and more easily solve various problems encountered. An expert system is one of the groups of knowledge in information technology that is able to have knowledge and intelligence like an expert who can diagnose a problem and provide the solutions needed to solve the problem. Where the concept of an expert system is how the knowledge of an expert is transferred into a computer so that the computer is able to think and act like an expert in diagnosing problems. Therefore, it is possible for humans to consult with computers and no longer need experts [2].

Expert systems are very beneficial for humans, where an expert can be duplicated as much as humans want to meet existing needs, so this is very economically beneficial. As explained earlier, there are not many beginner cassava farmers who do not know the diseases that attack cassava plants, thus providing an obstacle for farmers in diagnosing cassava diseases that they are planting, whereas there are only a few farmers that they can make a consultation place to ask questions about the problem. Therefore, the phenomenon is that there are few experts or farmers who really understand the disease in cassava plants while the need for experts or farmers who understand cassava plant diseases is quite high plus the use of the services of an expert tends to be quite expensive so it is not economical [3].

To that end, these problems can be answered by implementing an expert system to help cassava farmers to 
diagnose and overcome various diseases that attack the plants they plant. Where the knowledge of a cassava plant disease expert will be transferred to a computer and then used into an expert system that can be used by thousands of cassava farmers throughout Indonesia in particular [4].

The expert system has several methods that can be applied, one of which is the Bayes method. Where this method will classify answers based on the probability of cases that occur so that the more cases that occur and are embedded into the knowledge base, the answers are given will be more accurate. This is quite in accordance with the ability of farmers who always learn from experience, with the Bayes method, this can be done so that the more experience is invested in the knowledge base, the answers given will be more accurate [5]-[7].

\section{METHOD}

Bayes theorem, taken from the name Rev. Thomas Bayes. In the 18th century Thomas Bayes, a British Presbyterian priest. Because of his interest in mathematics, Bayes tried to develop a formula to determine the probability that God really existed based on facts contained on earth. Then Laplace refined the findings and gave it the name "Bayes' Theorem" with the formula below: [8], [9]

$$
P(H \mid E)=\frac{P(E \mid H) x P(H)}{P(E)}
$$

Information:

$\mathrm{P}(\mathrm{H} \mid \mathrm{E})$ : Hypothesis probability $\mathrm{H}$ if there is evidence $\mathrm{E}$ $\mathrm{P}(\mathrm{E} \mid \mathrm{H})$ : Probability of $\mathrm{E}$ evidence to occur if $\mathrm{H}$ hypothesis is known

$\mathrm{P}(\mathrm{H})$ : $\mathrm{H}$ hypothesis probability regardless of any evidence

P (E) : Probability of evidence E

The application of the Bayes theorem to overcome uncertainty, if more than one evidence emerges is written as follows: [10]

Information:

$$
P(H \mid E, e)=\frac{P(e \mid E, H) \times P(H)}{P(e \mid E)}
$$

e : Old evidence

$\mathrm{P}(\mathrm{H} \mid \mathrm{E}, \mathrm{e})$ : The probability of a hypothesis $\mathrm{H}$, if new evidence emerges $\mathrm{E}$ from the old evidence e

$\mathrm{P}(\mathrm{e} \mid \mathrm{E}, \mathrm{H}) \quad$ : Probability of the relationship between $\mathrm{e}$ and $\mathrm{E}$ if the hypothesis $\mathrm{H}$ is true

$\mathrm{P}(\mathrm{e} \mid \mathrm{E}) \quad$ : Probability of relation between $\mathrm{e}$ and $\mathrm{E}$ regardless of any hypothesis

$\mathrm{P}(\mathrm{H} \mid \mathrm{E}) \quad$ : Hypothesis probability $\mathrm{H}$ if there is evidence $\mathrm{E}$

The formula for the conditional probability $\mathrm{P}\left(\mathrm{H}_{\mathrm{i}} \cap \mathrm{E}\right)$ for any event $\mathrm{E}$ in the Bayes algorithm can be written with the formula below: [11], [12]
$P\left(H_{i} \mid E_{1} E_{2} \ldots E_{m}\right)=\frac{P\left(E_{1} \mid H_{i}\right) \times P\left(E_{2} \mid H_{i}\right) x \ldots \times\left(E_{m} \mid H_{i}\right) x P\left(H_{i}\right)}{\sum_{k=1}^{n} P\left(E_{1} \mid H_{k}\right) \times P\left(E_{2} \mid H_{k}\right) x \ldots \times P\left(E_{m} \mid H_{k}\right) \times P\left(H_{k}\right)}$

Information:

$\mathrm{P}\left(\mathrm{H}_{\mathrm{i}} \mid \mathrm{E}\right) \quad$ : The conditional probability of a hypothesis $\mathrm{Hi}$ occurs if the evidence is provided

$\mathrm{P}\left(\mathrm{E} \mid \mathrm{H}_{\mathrm{i}}\right) \quad$ : The probability that an $\mathrm{E}$ proof occurs will affect the Hi hypothesis

$\mathrm{P}\left(\mathrm{H}_{\mathrm{i}}\right) \quad$ : The initial probability of the Hi hypothesis occurs regardless of any evidence

$\mathrm{P}(\mathrm{E}) \quad$ : The initial probability of evidence E occurs regardless of the hypothesis / other evidence.

The research methodology used in this study follows the following flow:

A. Problem analysis

Analyze the problems that occur that are the main topics in research to be resolved.

\section{B. Study of literature}

Look for a variety of literature both in books, national journals, international journals, and the results of other scientific work around the problem to be solved.

\section{Troubleshooting Analysis}

Analyze how problem-solving is the topic of research to be proposed as an alternative solution to the problem. To solve the problem that has been explained in the problem analysis, then we need a suitable algorithm that can be applied as problem-solving. the algorithm chosen is the Bayes algorithm. Bayes algorithm can be used to calculate the probability of an event occurring based on the effect obtained from the results of observations. So based on available data, the Bayes algorithm can calculate the probability of cassava-based on the symptoms experienced.

\section{Knowledge Base Design}

Design a knowledge base that will be used in expert systems as a source of knowledge in making a diagnosis. Based on statistical data of cassava disease taken at Binjai City Agriculture and Fisheries Office in 2018, there are 397 known cassava trees that have positive diseases with the following types of diseases:

Table 2. Number of Sufferers from Each Type of Cassava Disease

\begin{tabular}{clc}
\hline Symbol & Types of Cassava Diseases & Number of Sufferers \\
\hline H1 & Brown Leaf Spots & 78 \\
H2 & Baur Leaf Spots & 56 \\
H3 & White Leaf Spots & 87 \\
H4 & Leaf Bacteria & 48 \\
H5 & Anthracnose & 36 \\
H6 & Rot at the Base of the & 92 \\
& Stem/Root & TOTAL \\
\end{tabular}


Symptoms data for each cassava disease can be seen in the following table:

Table 3. Number of Each Symptom of Each Type of Cassava Disease

\begin{tabular}{|c|c|c|c|c|c|c|c|}
\hline \multirow[t]{2}{*}{ Symbol } & \multirow[t]{2}{*}{ Symptoms } & \multicolumn{6}{|c|}{$\begin{array}{c}\text { Number of Symptoms of } \\
\text { Each Type of Cassava } \\
\text { Disease }\end{array}$} \\
\hline & & H1 & H2 & H3 & H4 & H5 & H6 \\
\hline E1 & The disease attacks the old leaves & 76 & 55 & 76 & 0 & 0 & 12 \\
\hline E2 & Leaf spot on the bottom & 68 & 2 & 3 & 0 & 2 & 3 \\
\hline E3 & $\begin{array}{l}\text { White/brown patches on the top } \\
\text { of the leaf }\end{array}$ & 66 & 7 & 43 & 3 & 1 & 8 \\
\hline E4 & $\begin{array}{l}\text { The edges are fringed with purple } \\
\text { circles }\end{array}$ & 74 & 5 & 2 & 0 & 1 & 2 \\
\hline E5 & Brown spots on leaves & 54 & 48 & 2 & 7 & 1 & 8 \\
\hline E6 & Crimped leaves & 59 & 51 & 76 & 45 & 0 & 2 \\
\hline E7 & The leaves fall/fall & 64 & 2 & 87 & 3 & 5 & 9 \\
\hline E8 & Perforated leaf & 49 & 2 & 8 & 7 & 4 & 0 \\
\hline E9 & Yellowing of leaves & 77 & 24 & 65 & 34 & 1 & 90 \\
\hline E10 & Dried leaves & 62 & 34 & 86 & 41 & 8 & 43 \\
\hline E11 & $\begin{array}{l}\text { There is fungus at the bottom of } \\
\text { the leaf }\end{array}$ & 34 & 41 & 12 & 10 & 3 & 1 \\
\hline E12 & Large patches & 9 & 44 & 3 & 11 & 2 & 6 \\
\hline E13 & spots on the tips of le & 4 & 27 & 13 & 7 & 2 & 0 \\
\hline E14 & Inverted V-shaped patches & 7 & 39 & 0 & 3 & 1 & 0 \\
\hline E15 & The top leaves are brown evenly & 7 & 8 & 0 & 4 & 0 & 0 \\
\hline E16 & The lower leaves are gray & 3 & 21 & 7 & 9 & 2 & 3 \\
\hline E17 & $\begin{array}{l}\text { The middle of the gray patch } \\
\text { producing fungi }\end{array}$ & 1 & 0 & 82 & 9 & 2 & 5 \\
\hline E18 & Attacking young leaves & 0 & 2 & 69 & 0 & 1 & 16 \\
\hline E19 & Attacking leaves and stems & 0 & 1 & 16 & 29 & 1 & 11 \\
\hline E20 & $\begin{array}{l}\text { The initial symptoms are gray } \\
\text { lesions }\end{array}$ & 9 & 6 & 0 & 37 & 1 & 2 \\
\hline E21 & $\begin{array}{l}\text { The lesions are limited by the leaf } \\
\text { bones and form angles }\end{array}$ & 6 & 4 & 2 & 42 & 5 & 0 \\
\hline E22 & Lesion extends into necrotic spots & 4 & 8 & 5 & 44 & 7 & 0 \\
\hline E23 & $\begin{array}{l}\text { The bacterial mass that occurs in } \\
\text { the stem, leaf blades and stems }\end{array}$ & 3 & 3 & 11 & 39 & 9 & 0 \\
\hline E24 & withered plant tip & 7 & 2 & 1 & 45 & 11 & 4 \\
\hline E25 & $\begin{array}{l}\text { Attacking the surface of goods, } \\
\text { petioles, and leaves }\end{array}$ & 11 & 1 & 7 & 2 & 33 & 0 \\
\hline E26 & $\begin{array}{l}\text { There are protuberances on the } \\
\text { surface of the stem }\end{array}$ & 14 & 0 & 3 & 1 & 26 & 0 \\
\hline E27 & Petiole easily broke & 5 & 0 & 2 & 0 & 29 & 11 \\
\hline $\mathrm{E} 28$ & Withered leaves & 3 & 4 & 4 & 0 & 21 & 89 \\
\hline E29 & Shrinkage on the cor & 2 & 0 & 0 & 4 & 32 & 0 \\
\hline E30 & Stems break easily & 8 & 2 & 0 & 7 & 30 & 2 \\
\hline E31 & $\begin{array}{l}\text { Attacking the base of the stem, } \\
\text { roots, and tubers }\end{array}$ & 0 & 6 & 3 & 3 & 3 & 92 \\
\hline E32 & Premature deciduous leaves & 11 & 7 & 5 & 1 & 7 & 87 \\
\hline E33 & Color damage to roots & 12 & 2 & 8 & 2 & 3 & 91 \\
\hline E34 & Root rot & 4 & 2 & 9 & 1 & 0 & 89 \\
\hline E35 & The tubers are dark and stink & 6 & 1 & 9 & 1 & 1 & 90 \\
\hline
\end{tabular}

These data can be represented in the knowledge base of the expert system that will be built. Where

$\mathrm{P}(\mathrm{H}) \quad$ : Probability of occurrence of $\mathrm{H}$ disease regardless of anything

$\mathrm{P}(\mathrm{E} \mid \mathrm{H}) \quad$ : Probability of $\mathrm{E}$ symptoms to occur in $\mathrm{H}$ disease

In the data above, $\mathrm{P}(\mathrm{H} 1)$ can be found by dividing the number of $\mathrm{H} 1$ sufferers by the total cassava plants that are positive for cassava disease, which is $78 / 397=0.196474$, so that:

$\mathrm{P}(\mathrm{H} 1)=0.196474$.

The $\mathrm{P}(\mathrm{H})$ value of each disk can be seen in the following table:
Table 4. P (H) Values for Each Disease

\begin{tabular}{clcc}
\hline Symbol Types of Cassava Diseases & N. of Sufferers & $\mathbf{P}\left(\mathbf{P}_{\mathbf{1}}\right)$ \\
\hline H1 & Brown Leaf Spots & 78 & 0,196474 \\
H2 & Baur Leaf Spots & 56 & 0,141058 \\
H3 & White Leaf Spots & 87 & 0,219144 \\
H4 & Leaf Bacteria & 48 & 0,120907 \\
H5 & Anthracnose & 36 & 0,09068 \\
H6 & Rot at the Base of the Stem/Root & 92 & 0,231738 \\
\hline
\end{tabular}

Whereas to find $\mathrm{P}(\mathrm{E} \mid \mathrm{H})$ can be done by dividing the number of symptoms of $\mathrm{E}$ by the number of sufferers of $\mathrm{H}$, For example, to look for P (E1 | H1), then for the number of symptoms of E1 with the number of suffering from $\mathrm{H} 1$, it becomes $76 / 78=0.974359$. So that:

$\mathrm{P}(\mathrm{E} 1 \mid \mathrm{H} 1)=0.974359$.

The complete data of the $\mathrm{P}(\mathrm{E} \mid \mathrm{H})$ value for each symptom can be seen in the following table:

Table 5. P (E $\mid \mathrm{H})$ values for each symptom of each disease

\begin{tabular}{|c|c|c|c|c|c|c|c|}
\hline \multirow{2}{*}{ Symbol } & \multirow{2}{*}{ Symptoms } & \multicolumn{6}{|c|}{ Number of Symptoms of Each Type of Cassava Disease } \\
\hline & & $\mathbf{P}\left(\mathbf{E}_{\mathrm{i}} \mid \mathbf{H}_{1}\right)$ & $\mathbf{P}\left(\mathbf{E}_{\mathrm{i}} \mid \mathbf{H}_{2}\right)$ & $\mathbf{P}\left(\mathbf{E}_{\mathrm{i}} \mid \mathbf{H}_{3}\right)$ & $\mathbf{P}\left(\mathbf{E}_{\mathrm{i}} \mathbf{H}_{4}\right)$ & $\mathbf{P}\left(\mathbf{E}_{\mathrm{j}} \mid \mathbf{H}_{5}\right)$ & $\mathbf{P}\left(\mathbf{E}_{\mathrm{i}} \mid \mathbf{H}_{6}\right)$ \\
\hline E1 & $\begin{array}{l}\text { The disease } \\
\text { attacks the old } \\
\text { leaves }\end{array}$ & 0,974359 & 0,982143 & 0,873563 & 0 & 0 & 0,130435 \\
\hline E2 & $\begin{array}{l}\text { Leaf spot on the } \\
\text { bottom }\end{array}$ & 0,871795 & 0,035714 & 0,034483 & 0 & 0,055556 & 0,032609 \\
\hline E3 & $\begin{array}{l}\text { White/brown } \\
\text { patches on the } \\
\text { top of the leaf }\end{array}$ & 0,846154 & 0,125 & 0,494253 & 0,0625 & 0,027778 & 0,086957 \\
\hline E4 & $\begin{array}{l}\text { The edges are } \\
\text { fringed with } \\
\text { purple circles }\end{array}$ & 0,948718 & 0,089286 & 0,022989 & 0 & 0,027778 & 0,021739 \\
\hline E5 & $\begin{array}{l}\text { Brown spots on } \\
\text { leaves }\end{array}$ & 0,692308 & 0,857143 & 0,022989 & 0,145833 & 0,027778 & 0,086957 \\
\hline E6 & Crimped leaves & 0,75641 & 0,910714 & 0,873563 & 0,9375 & 0 & 0,021739 \\
\hline E7 & $\begin{array}{l}\text { The leaves } \\
\text { fall/fall }\end{array}$ & 0,820513 & 0,035714 & 1 & 0,0625 & 0,138889 & 0,097826 \\
\hline E8 & Perforated leaf & 0,628205 & 0,035714 & 0,091954 & 0,145833 & 0,111111 & 0 \\
\hline E9 & $\begin{array}{l}\text { Yellowing of } \\
\text { leaves }\end{array}$ & 0,987179 & 0,428571 & 0,747126 & 0,708333 & 0,027778 & 0,978261 \\
\hline E10 & Dried leaves & 0,794872 & 0,607143 & 0,988506 & 0,854167 & 0,222222 & 0,467391 \\
\hline E11 & $\begin{array}{l}\text { There is fungus } \\
\text { at the bottom of } \\
\text { the leaf }\end{array}$ & 0,435897 & 0,732143 & 0,137931 & 0,208333 & 0,083333 & 0,01087 \\
\hline E12 & Large patches & 0,115385 & 0,785714 & 0,034483 & 0,229167 & 0,055556 & 0,065217 \\
\hline E13 & $\begin{array}{l}\text { Often spots on } \\
\text { the tips of } \\
\text { leaves }\end{array}$ & 0,051282 & 0,482143 & 0,149425 & 0,145833 & 0,055556 & 0 \\
\hline E14 & $\begin{array}{l}\text { Inverted V- } \\
\text { shaped patches }\end{array}$ & 0,089744 & 0,696429 & 0 & 0,0625 & 0,027778 & 0 \\
\hline E15 & $\begin{array}{l}\text { The top leaves } \\
\text { are brown } \\
\text { evenly }\end{array}$ & 0,089744 & 0,142857 & 0 & 0,083333 & 0 & 0 \\
\hline E16 & $\begin{array}{l}\text { The lower } \\
\text { leaves are gray }\end{array}$ & 0,038462 & 0,375 & 0,08046 & 0,1875 & 0,055556 & 0,032609 \\
\hline E17 & $\begin{array}{l}\text { The middle of } \\
\text { the gray patch } \\
\text { producing fungi }\end{array}$ & 0,012821 & 0 & 0,942529 & 0,1875 & 0,055556 & 0,054348 \\
\hline E18 & $\begin{array}{l}\text { Attacking } \\
\text { young leaves } \\
\text { Attacking }\end{array}$ & 0 & 0,035714 & 0,793103 & 0 & 0,027778 & 0,173913 \\
\hline E19 & $\begin{array}{l}\text { leaves and } \\
\text { stems }\end{array}$ & 0 & 0,017857 & 0,183908 & 0,604167 & 0,027778 & 0,119565 \\
\hline E20 & $\begin{array}{l}\text { The initial } \\
\text { symptoms are } \\
\text { gray lesions }\end{array}$ & 0,115385 & 0,107143 & 0 & 0,770833 & 0,027778 & 0,021739 \\
\hline E21 & $\begin{array}{l}\text { The lesions are } \\
\text { limited by the } \\
\text { leaf bones and } \\
\text { form angles }\end{array}$ & 0,076923 & 0,071429 & 0,022989 & 0,875 & 0,138889 & 0 \\
\hline E22 & $\begin{array}{l}\text { Lesion extends } \\
\text { into necrotic } \\
\text { spots }\end{array}$ & 0,051282 & 0,142857 & 0,057471 & 0,916667 & 0,194444 & 0 \\
\hline E23 & $\begin{array}{l}\text { The bacterial } \\
\text { mass that occurs }\end{array}$ & 0,038462 & 0,053571 & 0,126437 & 0,8125 & 0,25 & 0 \\
\hline
\end{tabular}




\begin{tabular}{|c|c|c|c|c|c|c|c|}
\hline \multirow[b]{2}{*}{ Symbol } & \multirow{2}{*}{ Symptoms } & \multicolumn{6}{|c|}{ Number of Symptoms of Each Type of Cassava Disease } \\
\hline & & $\mathbf{P}\left(\mathbf{E}_{j} \mid \mathbf{H}_{1}\right)$ & $\mathbf{P}\left(\mathbf{E}_{\mathrm{i}} \mid \mathbf{H}_{2}\right)$ & $\mathbf{P}\left(\mathbf{E}_{\mathrm{i}} \mid \mathbf{H}_{3}\right)$ & $\mathbf{P}\left(\mathbf{E}_{\mathrm{i}} \mid \mathbf{H}_{4}\right)$ & $\mathbf{P}\left(\mathbf{E}_{j} \mid \mathbf{H}_{5}\right)$ & $\mathbf{P}\left(\mathbf{E}_{\mathrm{j}} \mid \mathbf{H}_{6}\right)$ \\
\hline & $\begin{array}{l}\text { in the stem, leaf } \\
\text { blades and } \\
\text { stems }\end{array}$ & & & & & & \\
\hline E24 & $\begin{array}{l}\text { Withered plant } \\
\text { tip }\end{array}$ & 0,089744 & 0,035714 & 0,011494 & 0,9375 & 0,305556 & 0,043478 \\
\hline E25 & $\begin{array}{l}\text { Attacking the } \\
\text { surface of } \\
\text { goods, petioles, } \\
\text { and leaves }\end{array}$ & 0,141026 & 0,017857 & 0,08046 & 0,041667 & 0,916667 & 0 \\
\hline E26 & $\begin{array}{l}\text { There are } \\
\text { protuberances } \\
\text { on the surface } \\
\text { of the stem }\end{array}$ & 0,179487 & 0 & 0,034483 & 0,020833 & 0,722222 & 0 \\
\hline E27 & $\begin{array}{l}\text { Petiole easily } \\
\text { broke }\end{array}$ & 0,064103 & 0 & 0,022989 & 0 & 0,805556 & 0,119565 \\
\hline E28 & Withered leaves & 0,038462 & 0,071429 & 0,045977 & 0 & 0,583333 & 0,967391 \\
\hline E29 & $\begin{array}{l}\text { Shrinkage on } \\
\text { the cork }\end{array}$ & 0,025641 & 0 & 0 & 0,083333 & 0,888889 & 0 \\
\hline E30 & $\begin{array}{l}\text { Stems break } \\
\text { easily }\end{array}$ & 0,102564 & 0,035714 & 0 & 0,145833 & 0,833333 & 0,021739 \\
\hline E31 & $\begin{array}{l}\text { Attacking the } \\
\text { base of the } \\
\text { stem, roots, and } \\
\text { tubers }\end{array}$ & 0 & 0,107143 & 0,034483 & 0,0625 & 0,083333 & 1 \\
\hline E32 & $\begin{array}{l}\text { Premature } \\
\text { deciduous } \\
\text { leaves }\end{array}$ & 0,141026 & 0,125 & 0,057471 & 0,020833 & 0,194444 & 0,945652 \\
\hline E33 & $\begin{array}{l}\text { Color damage to } \\
\text { roots }\end{array}$ & 0,153846 & 0,035714 & 0,091954 & 0,041667 & 0,083333 & 0,98913 \\
\hline E34 & Root rot & 0,051282 & 0,035714 & 0,103448 & 0,020833 & 0 & 0,967391 \\
\hline E35 & $\begin{array}{l}\text { The tubers are } \\
\text { dark and stink }\end{array}$ & 0,076923 & 0,017857 & 0,103448 & 0,020833 & 0,027778 & 0,978261 \\
\hline
\end{tabular}

\section{E. Analysis of the Process in Diagnosing}

The process of calculating the results using the Bayes algorithm in full is described in the form of a flowchart below. All symptoms entered by the user will be processed to find the conclusion. The processing showed at the flowchart below:

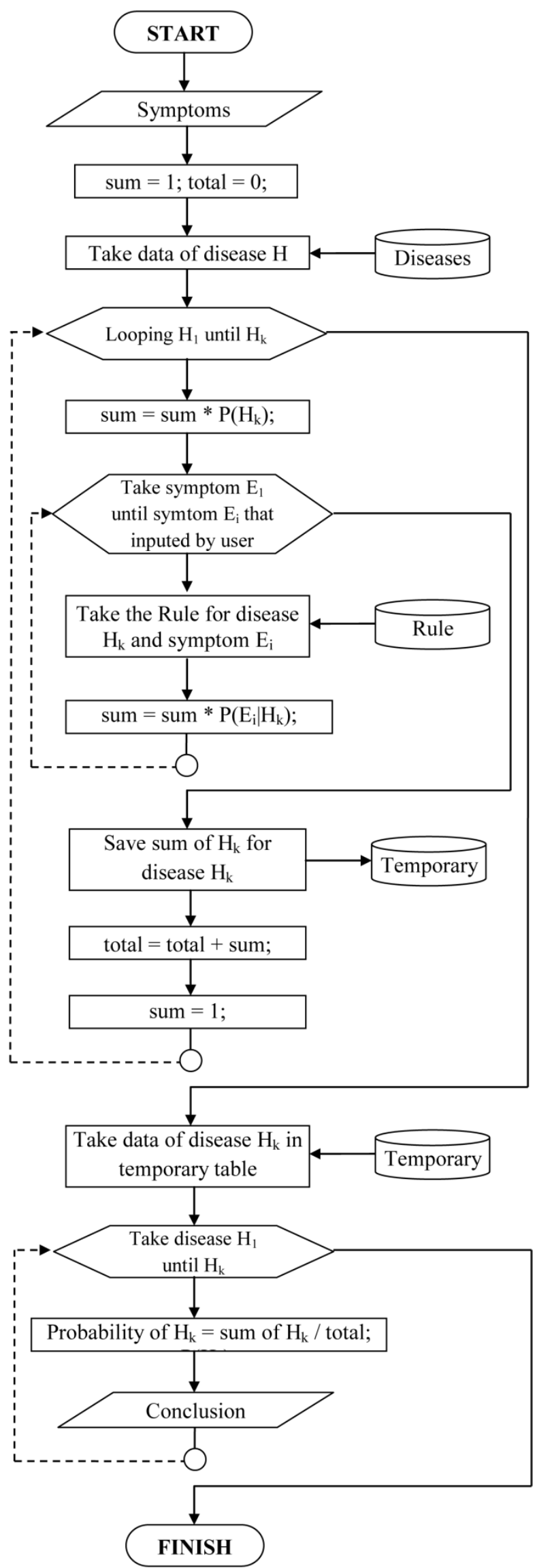

Figure 1. Flowchart Process for Diagnosing Types of Cassava Disease 


\section{F. $\quad$ Testing and Analysis}

Analyze the results of tests that have been done to give an idea of how effectively the expert system can solve the problem.

\section{G. Conclusion}

Make the conclusions from the results of testing and analysis of an expert system test that was successfully built.

\section{RESULTS AND DISCUSSION}

The results of this study are demonstrated through the testing. Testing is done by selecting the following symptoms:

1. Disease attacks old leaves (E1)

2. Spots fringed with purple circles (E4)

3. There is mold on the underside of the leaf (E11)

4. The lower leaves are gray (E16)

5. Withered plant tip (E24)

To find the probability of an $\mathrm{H}$ disease based on the $\mathrm{E}$ symptoms that arise, then the following equation is used:

$P\left(H_{i} \mid E_{1} E_{2} \ldots E_{3}\right)=\frac{P\left(E_{1} \mid H_{i}\right) \times P\left(E_{2} \mid H_{i}\right) \times \ldots \times P\left(E_{m} \mid H_{i}\right) \times P\left(H_{i}\right)}{\sum_{k=1}^{n} P\left(E_{1} \mid H_{k}\right) \times P\left(E_{2} \mid H_{k}\right) \times \ldots \times P\left(E_{m} \mid H_{k}\right) \times P\left(H_{k}\right)}$

Based on the above equation, it is possible to find the probability of each $\mathrm{H} 1$ disease, up to $\mathrm{H} 6$ as follows :

\section{H1 (Brown Leaf Spots)}

$P\left(H_{1} \mid E_{1} E_{4} E_{11} E_{16} E_{24}\right)$

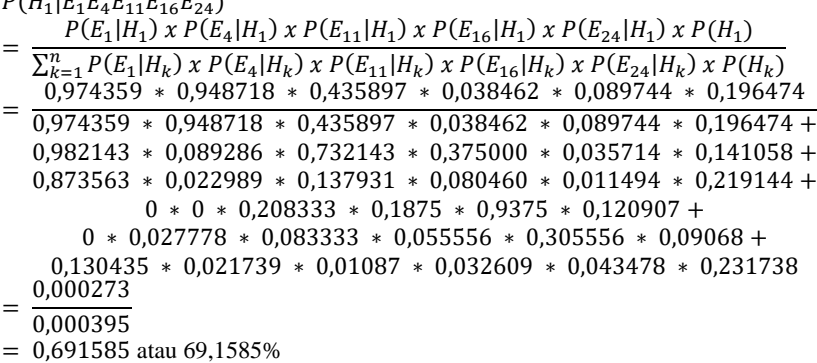

\section{H2 (Baur Leaf Spots)}

$P\left(H_{2} \mid E_{1} E_{4} E_{11} E_{16} E_{24}\right)$

$P\left(E_{1} \mid H_{2}\right) \times P\left(E_{4} \mid H_{2}\right) \times P\left(E_{11} \mid H_{2}\right) \times P\left(E_{16} \mid H_{2}\right) \times P\left(E_{24} \mid H_{2}\right) \times P\left(H_{2}\right)$

$=\frac{\sum_{k=1}^{n} P\left(E_{1} \mid H_{k}\right) \times P\left(E_{4} \mid H_{k}\right) \times P\left(E_{11} \mid H_{k}\right) \times P\left(E_{16} \mid H_{k}\right) \times P\left(E_{24} \mid H_{k}\right) \times P\left(H_{k}\right)}{\sum_{0,3}}$ $0,982143 * 0,089286 * 0,732143 * 0,375000 * 0,035714 * 0,141058$

$=\frac{0,982143 * 0,089286 * 0,732143 * 0,375000 * 0,035714 * 0,141058}{0,974359 * 0,948718 * 0,435897 * 0,038462 * 0,089744 * 0,196474+}$ $0,982143 * 0,089286 * 0,732143 * 0,375000 * 0,035714 * 0,141058+$ $0,873563 * 0,022989 * 0,137931 * 0,080460 * 0,011494 * 0,219144+$ $0 * 0 * 0,208333 * 0,1875 * 0,9375 * 0,120907+$

$0 * 0,027778 * 0,083333 * 0,055556 * 0,305556 * 0,09068+$ $0,130435 * 0,021739 * 0,01087 * 0,032609 * 0,043478 * 0,231738$ 0,000121

0,000395

$=0,306969$ atau $30,6969 \%$

\section{H3 (White Leaf Spots)}

\section{$P\left(H_{3} \mid E_{1} E_{4} E_{11} E_{16} E_{24}\right)$}

$P\left(E_{1} \mid H_{3}\right) \times P\left(E_{4} \mid H_{3}\right) \times P\left(E_{11} \mid H_{3}\right) \times P\left(E_{16} \mid H_{3}\right) \times P\left(E_{24} \mid H_{3}\right) \times P\left(H_{3}\right)$

$=\frac{P}{\sum_{k=1}^{n} P\left(E_{1} \mid H_{k}\right) \times P\left(E_{4} \mid H_{k}\right) \times P\left(E_{11} \mid H_{k}\right) \times P\left(E_{16} \mid H_{k}\right) \times P\left(E_{24} \mid H_{k}\right) \times P\left(H_{k}\right)}$ $0,873563 * 0,022989 * 0,137931 * 0,080460 * 0,011494 * 0,219144$

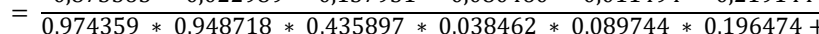
$0,982143 * 0,089286 * 0,732143 * 0,375000 * 0,035714 * 0,141058+$ $0,873563 * 0,022989 * 0,137931 * 0,080460 * 0,011494 * 0,219144+$ $0 * 0 * 0,208333 * 0,1875 * 0,9375 * 0,120907+$

$0 * 0,027778 * 0,083333 * 0,055556 * 0,305556 * 0,09068+$

$0,130435 * 0,021739 * 0,01087 * 0,032609 * 0,043478 * 0,231738$ $0,130435 * 0,02$
0,0000005614

$=\frac{0,000395}{0,001420778}$

$=0,001420778$ atau $0,1421 \%$

\section{H4 (Leaf Bacteria)}

$P\left(H_{4} \mid E_{1} E_{4} E_{11} E_{16} E_{24}\right)$

$$
\begin{aligned}
& P\left(H_{4} \mid E_{1} E_{4} E_{11} E_{16} E_{24}\right) \\
&= \frac{P\left(E_{1} \mid H_{4}\right) \times P\left(E_{4} \mid H_{4}\right) \times P\left(E_{11} \mid H_{4}\right) \times P\left(E_{16} \mid H_{4}\right) \times P\left(E_{24} \mid H_{4}\right) \times P\left(H_{4}\right)}{\sum_{k=1}^{n} P\left(E_{1} \mid H_{k}\right) \times P\left(E_{4} \mid H_{k}\right) \times P\left(E_{11} \mid H_{k}\right) \times P\left(E_{16} \mid H_{k}\right) \times P\left(E_{24} \mid H_{k}\right) \times P\left(H_{k}\right)} \\
&= \frac{0 * 0 * 0,208333 * 0,1875 * 0,9375 * 0,120907}{0,974359 * 0,948718 * 0,435897 * 0,038462 * 0,089744 * 0,196474+} \\
& 0,982143 * 0,089286 * 0,732143 * 0,375000 * 0,035714 * 0,141058+ \\
& 0,873563 * 0,022989 * 0,137931 * 0,080460 * 0,011494 * 0,219144+ \\
& 0 * 0 * 0,208333 * 0,1875 * 0,9375 * 0,120907+ \\
& 0 * 0,027778 * 0,083333 * 0,055556 * 0,305556 * 0,09068+ \\
&= \frac{0}{0,000395} \\
&= 0 \text { atau } 0 \%
\end{aligned}
$$

\section{H5 (Anthracnose)}

$P\left(H_{5} \mid E_{1} E_{4} E_{11} E_{16} E_{24}\right)$

$$
\begin{aligned}
= & \frac{P\left(E_{1} \mid H_{5}\right) \times P\left(E_{4} \mid H_{5}\right) \times P\left(E_{11} \mid H_{5}\right) \times P\left(E_{16} \mid H_{5}\right) \times P\left(E_{24} \mid H_{5}\right) \times P\left(H_{5}\right)}{\sum_{k=1}^{n} P\left(E_{1} \mid H_{k}\right) \times P\left(E_{4} \mid H_{k}\right) \times P\left(E_{11} \mid H_{k}\right) \times P\left(E_{16} \mid H_{k}\right) \times P\left(E_{24} \mid H_{k}\right) \times P\left(H_{k}\right)} \\
= & \frac{0 * 0,027778 * 0,083333 * 0,055556 * 0,305556 * 0,09068}{0,974359 * 0,948718 * 0,435897 * 0,038462 * 0,089744 * 0,196474+} \\
& 0,982143 * 0,089286 * 0,732143 * 0,375000 * 0,035714 * 0,141058+ \\
& 0,873563 * 0,022989 * 0,137931 * 0,080460 * 0,011494 * 0,219144+ \\
& 0 * 0 * 0,208333 * 0,1875 * 0,9375 * 0,120907+ \\
& 0 * 0,027778 * 0,083333 * 0,055556 * 0,305556 * 0,09068+ \\
& 0,130435 * 0,021739 * 0,01087 * 0,032609 * 0,043478 * 0,231738 \\
= & \frac{0}{0,000395} \\
= & 0 \text { atau } 0 \%
\end{aligned}
$$

$=0$ atau $0 \%$

\section{H6 (Rot at the Base of the Stem/Root)}

$P\left(H_{6} \mid E_{1} E_{4} E_{11} E_{16} E_{24}\right)$

$$
P\left(E_{1} \mid H_{6}\right) \times P\left(E_{4} \mid H_{6}\right) \times P\left(E_{11} \mid H_{6}\right) \times P\left(E_{16} \mid H_{6}\right) \times P\left(E_{24} \mid H_{6}\right) \times P\left(H_{6}\right)
$$

$=\frac{P\left(E_{1} \mid E_{6}\right) \times\left(E_{1}\right) \times P\left(E_{4} \mid H_{k}\right) \times P\left(E_{11} \mid H_{k}\right) \times P\left(E_{16} \mid H_{k}\right) \times P\left(E_{24} \mid H_{k}\right) \times P\left(H_{k}\right)}{\sum_{k=1} P\left(E_{1} \mid H_{k}\right.}$ $0,130435 * 0,021739 * 0,01087 * 0,032609 * 0,043478 * 0,231738$

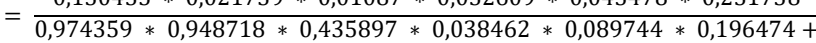
$0,982143 * 0,089286 * 0,732143 * 0,375000 * 0,035714 * 0,141058+$ $0,873563 * 0,022989 * 0,137931 * 0,080460 * 0,011494 * 0,219144+$ $0 * 0 * 0,208333 * 0,1875 * 0,9375 * 0,120907+$

$0 * 0,027778 * 0,083333 * 0,055556 * 0,305556 * 0,09068+$

$0,130435 * 0,021739 * 0,01087 * 0,032609 * 0,043478 * 0,231738$ $=\frac{0,0000000101}{0,000395}$

$=0,0000256284$ atau $0,0026 \%$

Based on the calculation above, it can be seen that, the user who inputted symptoms:

1. Disease attacks old leaves (E1)

2. Spots fringed with purple circles (E4)

3. There is mold on the underside of the leaf (E11)

4. The lower leaves are gray (E16)

5. Withered plant tip (E24)

The result showed $69.1585 \%$ of the cassava trees were currently getting Brown Leaf Spots (H1) disease. Other possibilities that can occur based on the results of calculations are:

Table 6. List of Possibilities for Other Diseases

\begin{tabular}{rlc}
\hline No & \multicolumn{1}{c}{ Disease } & Probability (\%) \\
\hline 1 & Baur Leaf Spots & 30,6969 \\
2 & White Leaf Spots & 0,1421 \\
3 & Rot at the Base of the Stem/Root & 0,0026 \\
4 & Leaf Bacteria & 0 \\
5 & Anthracnose & 0 \\
\hline
\end{tabular}

The results with the application can be seen in the following image: 
Sistem Pakar Mendiagnosa Penyakit Tanaman Singkong dengan Metode Bayes

Bercak Daun Coklat dengan presentase kemungkinan 69.16\%
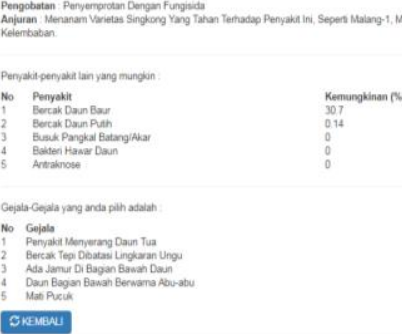

Figure 2. Results of the Process to Diagnose with the Application

\section{IV.CONCLUSION}

Based on the results of the analysis and testing conducted, the conclusions can be drawn in this study as follows:

1. The expert system with Bayes method can be an inexpensive and easy solution for farmers to diagnose diseases in cassava plants.

2. Bayes method is able to calculate the percentage of the likelihood of a disease based on the symptoms entered by the user, where the higher the percentage of the disease, the higher the likelihood of the disease occurring.

3. Bayes method is suitable to be implemented in expert system applications to diagnose cassava plant diseases.

4. If the user gives random symptoms, the application will still provide diagnosis results. In the Bayes method, the more patient data that is successfully collected as a knowledge base, the more precise or accurate the results obtained.

\section{REFERENCES}

[1] Minarni, I. Warman, and W. Handayani, "Case-Based Reasoning (CBR) pada Sistem Pakar Identifikasi Hama dan Penyakit Tanaman Singkong dalam Usaha Meningkatkan Produktivitas Tanaman Pangan," $J$. TEKNOIF, vol. 5, no. 1, pp. 41-47, 2017.

[2] A. Barus, V. M., Mesran, M., Suginam, S., \& Karim, "Sistem pakar untuk mendiagnosis hama pada tanaman jambu biji menggunakan metode bayes.," J. Ilm. INFOTEK, 2(1)., 2017.

[3] S. Rahayu, "Sistem pakar untuk mendiagnosa penyakit gagal ginjal dengan menggunakan metode bayes.," Pelita Inform. Inf. dan Inform. 4(3)., 2013.

[4] H. T. Sihotang, "Perancangan Aplikasi Sistem Pakar Diagnosa Diabetes Dengan Metode Bayes.," J. Mantik Penusa, 1(1)., 2017.

[5] H. T. Sihotang, "Sistem pakar untuk mendiagnosa penyakit pada tanaman jagung dengan metode bayes.," J. Inform. Pelita Nusantara, 3(1)., 2018.

[6] H. Sihotang, H. T., Panggabean, E., \& Zebua, "Sistem Pakar Mendiagnosa Penyakit Herpes Zoster Dengan Menggunakan Metode Teorema Bayes.," J. Inform. Pelita Nusantara, 3(1)., 2018.
I. Candra Dewi, A. Andy Soebroto, and M. Tanzil Furqon, "Sistem Pakar Diagnosa Penyakit Sapi Potong Dengan Metode Naive Bayes," J. Enviromental Eng. Sustain. Technol., vol. 2, no. 2, pp. 72-78, 2015.

[8] D. Luciani et al., "Bayes pulmonary embolism assisted diagnosis: A new expert system for clinical use," Emerg. Med. J., vol. 24, no. 3, pp. 157-164, 2007.

[9] L. I. Jin-jua, X. I., \& Shu-hongb, "Research on sheep disease diagnostic expert system based on subjective Bayes algorithm with self-learning.," J. Hunan Univ. Sci. Technol. (Natural Sci. Ed. 1., 2009.

[10] A. Sarwar, "abid savar-Intelligent Naïve Bayes Approach to Diagnose-2012.pdf," no. November, pp. 14-16, 2012.

[11] P. Soepomo, "Sistem Pakar Untuk Mengidentifikasi Penyakit Udang Galah Dengan Metode Theorema Bayes," Sist. Pakar Untuk Mengidentifikasi Penyakit Udang Galah Dengan Metod. Theorema Bayes, vol. 1, no. 1, pp. 11-20, 2013.

[12] S. Winiarti, "JURNAL INFORMATIKA Vol 2, No. 2, Juli 2008," Pemanfaat. Teorema Bayes Dalam Penentuan Penyakit THT, vol. 2, no. 2, pp. 209-219, 2008. 